\title{
Oral DDAVP is a Good Alternative Therapy for Patients with Central Diabetes Insipidus: Experience of Five-Year Treatment
}

\author{
IZUMI FUKUDA, NAOMI HIZUKA AND KAZUE TAKANO \\ Department of Medicine II, Tokyo Women's Medical University, Tokyo 162-8666, Japan
}

\begin{abstract}
We studied the efficacy and safety of oral 1-deamino-8-D-arginine-vasopressin (DDAVP) tablets in 9 patients, aged 17-36 years, with central diabetes insipidus (DI). The tablet contained $100 \mu \mathrm{g}$ of desmopressin acetate. Maximum plasma concentration was obtained at 90 min after a single oral administration of $100 \mu \mathrm{g}$ DDAVP with a mean plasma level of $14.7 \pm 5.4$ (range: $5.3-50.9$ ) $\mathrm{pg} / \mathrm{ml}$. The onset of action was observed $2 \mathrm{~h}$ after oral administration, while the maximum effect was obtained at $4 \mathrm{~h}$. Mean urine volume in patients decreased significantly from $402 \pm 52$ to $26 \pm 3 \mathrm{ml} / \mathrm{hr}$ and urine osmolality increased from $91 \pm 8$ to $732 \pm 21 \mathrm{mosm} / \mathrm{kg}$ at $4 \mathrm{~h}$ after the intake of oral DDAVP. Plasma osmolality level and serum sodium concentration remained unchanged throughout the study. Long-term treatment for 5 years with oral DDAVP resulted in control of diuresis in 8 of the 9 patients. The average oral DDAVP dose required to obtain this control was $19 \pm 2$ (range: 15-30) times more than that of prior intranasal treatment. No adverse effects were observed during this follow-up period. These results indicate that oral DDAVP is a safe therapeutic agent that may be a good alternative treatment of central DI, particularly in patients who have chronic rhinitis and visual disturbances.
\end{abstract}

Key words: Oral DDAVP, Central diabetes insipidus

(Endocrine Journal 50: 437-443, 2003)

SINCE the 1970s, patients with central diabetes insipidus (DI) have been treated successfully with 1deamino-8-D-arginine-vasopressin (DDAVP), a synthetic analogue of arginine vasopressin (AVP). Although DDAVP is usually administered intranasally, oral treatment would be advantageous in certain clinical situations such as infants, elderly patients and patients with visual disturbances or with chronic rhinitis. Previously it was thought that peptides were generally poorly absorbed from the gastrointestinal tract as a consequence of being degraded to amino acids by enzymes in the intestinal lumen. However, in the 1980s, it was reported that DDAVP was absorbed unaltered from the gastrointestinal tract after oral administration thereby producing a dose dependent antidiuretic response in humans [1-3]. Furthermore, Fjellestad and

Received: December 2, 2002

Accepted: April 8, 2003

Correspondence to: Dr. Izumi FUKUDA, Department of Medicine II, Tokyo Women's Medical University, 8-1 Kawada-cho, Shinjuku-ku, Tokyo 162-8666, Japan
Czernichow [4] demonstrated that oral DDAVP was effective in controlling central DI in children. On the basis of these findings the present study assessed the efficacy of oral DDAVP tablets after a single administration and also after 5 years of treatment in patients with central DI associated with multiple anterior pituitary hormone deficiencies.

\section{Patients and Methods}

\section{Patients}

Nine patients with central DI ( 5 males, 4 females; mean age $24 \pm 2.4 \mathrm{yr}$, range $17-36 \mathrm{yr}$ ) were invited to participate in a study assessing the effectiveness of oral DDAVP. The study protocol was approved by our institutional Ethics Committee and written informed consent was obtained from each patient prior to the study. The clinical details of the patients are summarized in Table 1 and show that the causes of DI were craniopharyngioma $(n=4)$, germinoma $(n=3)$ 
Table 1. Profiles of the patients with central DI

\begin{tabular}{cclcccc}
\hline \multirow{2}{*}{ \# } & Age, sex & & \multicolumn{3}{c}{ Anterior pituitary hormone deficits in addition to DI } \\
\cline { 4 - 7 } & & & GH & TSH & ACTH & Gonadotropin \\
\hline 1. & $17 \mathrm{~F}$ & craniopharyngioma (post surgery, RT) & + & + & + & + \\
2. & $18 \mathrm{M}$ & craniopharyngioma (post surgery, RT) & $+*$ & + & + & + \\
3. & $19 \mathrm{~F}$ & germinoma (post RT) & $+*$ & - & - & + \\
4. & $20 \mathrm{~F}$ & germinoma (post surgery, RT) & $+*$ & + & - & + \\
5. & $21 \mathrm{M}$ & idiopathic & $+*$ & + & - & + \\
6. & $28 \mathrm{~F}$ & craniopharyngioma (post surgery) & $+*$ & + & + & + \\
7. & $30 \mathrm{M}$ & craniopharyngioma (post surgery) & + & + & + & + \\
8. & $33 \mathrm{M}$ & germinoma (post RT) & $+*$ & + & + & + \\
9. & $36 \mathrm{M}$ & idiopathic & + & - & - & - \\
\hline
\end{tabular}

*: without replacement

RT: conventional radiation therapy -: preserved

and idiopathic etiology $(\mathrm{n}=2)$. In addition to DI, all of the patients had multiple anterior pituitary hormone deficiencies in various combinations. Two patients (Cases 1 and 2) had visual disturbances while 4 patients (Cases 3-6) had rhinitis. All the patients were receiving suitable hormone replacement therapy and were in stable clinical condition. Prior to the study polyuria in all the patients had been controlled with intranasal DDAVP. This treatment was discontinued for up to 1 day before the study, except in 2 patients who were administered DDAVP $20 \mathrm{~h}$ (Case 1) and $12 \mathrm{~h}$ (Case 4) prior to commencement.

\section{DDAVP tablets}

DDAVP tablets containing $100 \mu \mathrm{g}$ of desmopressin acetate $\left(\right.$ Minirine $\left.^{\mathrm{R}}\right)$ were kindly provided by Ferring AB Pharmaceuticals (Malmo, Sweden).

\section{Study protocol}

Intranasal DDAVP was discontinued for one day prior to the study and water intake ad libitum was allowed until the end of the single administration study. The patients came to the hospital after a $12 \mathrm{~h}$ overnight fast. At 0730 they emptied their bladders followed by measurement of body weight. The urine volume before and after this voiding were recorded. At 0800 the first blood sample was collected after which all but one of the patients received a tablet containing $100 \mu \mathrm{g}$ of DDAVP. The remaining patient (Case 1) received $200 \mu \mathrm{g}$ of DDAVP as she had previously required a higher dose of intranasal DDAVP $(30 \mu \mathrm{g} /$ day $)$ to achieve suitable control. Urine volume, plasma and urine osmolality (Posm and Uosm), serum sodium and plasma DDAVP concentrations were measured at baseline, every $30 \mathrm{~min}$ for the first $2 \mathrm{~h}$ and at $3,4,6$ and $8 \mathrm{~h}$ after DDAVP administration. The patients had lunch after blood and urine collection of $4 \mathrm{~h}$.

Following completion of the study on short-term DDAVP treatment, 8 of the patients were monitored for a period of $5 \mathrm{yr}$ at outpatient clinics, during which time they took oral DDAVP before eating. The patients were required to take an additional tablet if they had polyuria as they did previously. Body weight, blood pressure, Posm, Uosm, urine analysis, hematological data, serum electrolytes and liver and renal function were recorded at once every three months.

\section{Laboratory methods}

Plasma DDAVP was assayed at the laboratory of Ferring AB Pharmaceuticals (Malmo, Sweden) using a specific DDAVP radioimmunoassay after extraction according to the method of Lundin et al. [5]. Plasma and urine osmolalities and serum sodium concentration were determined by standard laboratory techniques. Urine volume was expressed as $\mathrm{ml}$ per hour.

\section{Statistics}

Statistical analyses were performed using StatView ${ }^{\mathrm{R}}$ 5.0 (SAS Institute Inc., USA). All data are expressed as mean \pm SEM. Repeated measures ANOVA tests were used to assess the differences in urine volume, serum sodium, Posm and Uosm before and after the administration of oral DDAVP with the level of significance being established at $\mathrm{P}<0.05$. 


\section{Results}

\section{Single administration study}

In the 8 patients who took $100 \mu \mathrm{g}$ of DDAVP the mean concenration of plasma DDAVP increased to $10.6 \pm 2.5$ and $14.7 \pm 5.4 \mathrm{pg} / \mathrm{ml}$ after 60 and $90 \mathrm{~min}$, respectively. The DDAVP levels gradually decreased in the following $3 \mathrm{~h}$ (Fig. 1). In the remaining patient (Case 1) administered $200 \mu \mathrm{g}$ of DDAVP, a peak plasma DDAVP concentration of $26.7 \mathrm{pg} / \mathrm{ml}$ was achieved after $1 \mathrm{~h}$.

Baseline urine volume varied from 148 to $642 \mathrm{ml} / \mathrm{h}$ (mean $402 \pm 52 \mathrm{ml} / \mathrm{h}$ ) and in all patients was observed to decrease $1 \mathrm{~h}$ after DDAVP administration (Fig. 2, Table 2). Accordingly, diuresis remained significantly low for up to $8 \mathrm{~h}$ with the minimum urine volume observed from 3 to $6 \mathrm{~h}$ after administration. Mean nadir

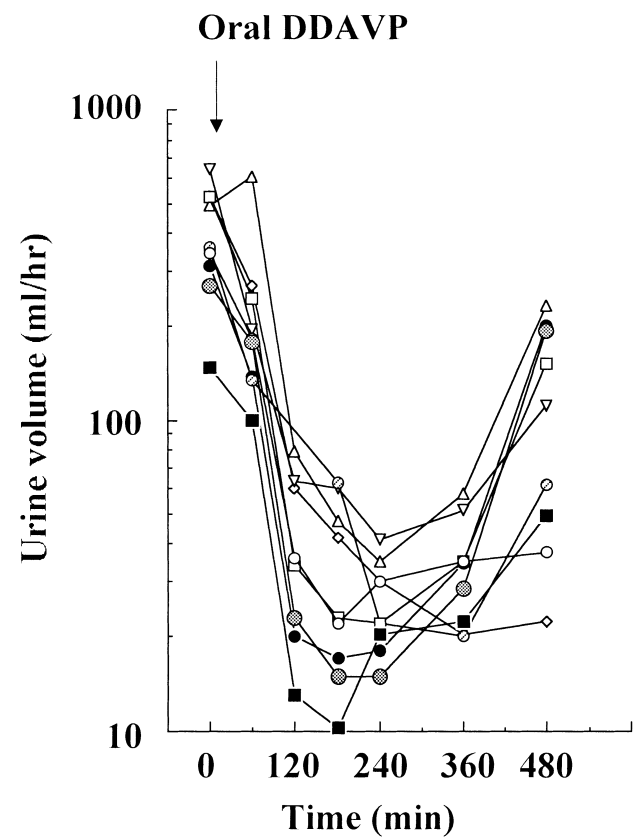

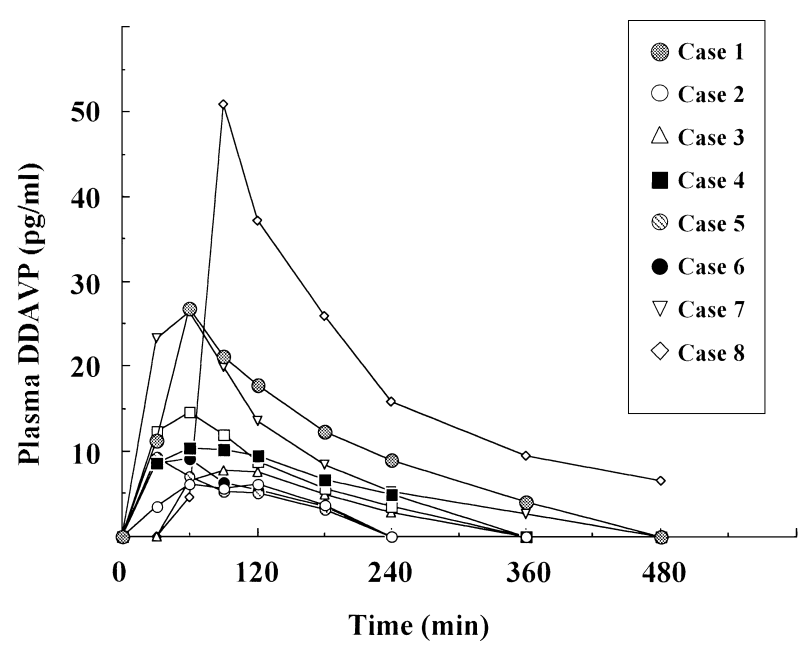

Fig. 1. Plasma DDAVP levels in 9 patients with DI after oral DDAVP administration. $\bigcirc 200 \mu \mathrm{g}$ administration (Case 1). Each case is represented by a different symbol.

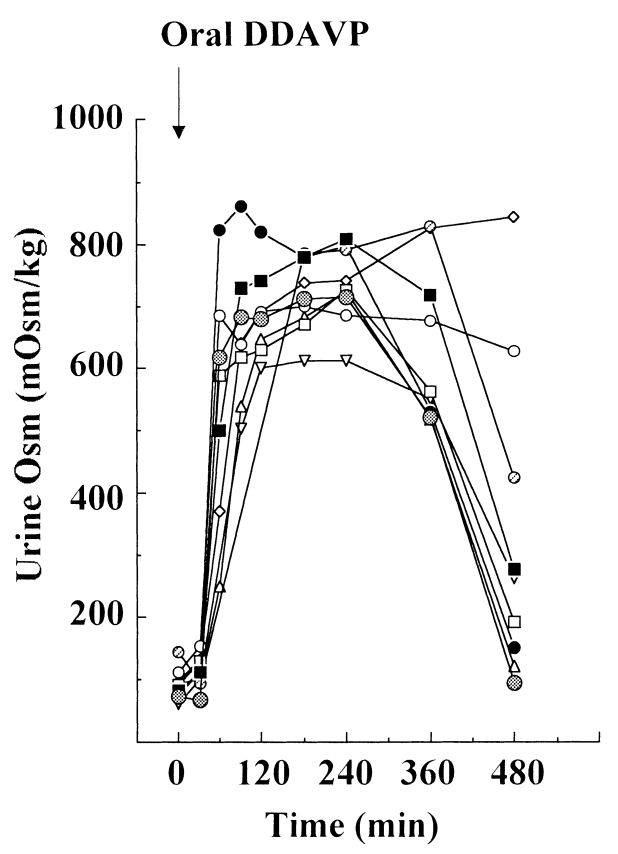

Fig. 2. Urine volumes and urine osmolality in nine patients with DI after oral DDAVP administration. Symbols representing each case are the same as used in Fig. 1.

Table 2. Changes in urine volume, plasma and urine osmolality and serum sodium levels in patients with DI after oral DDAVP administration.

\begin{tabular}{lccccccc}
\hline & $0(\mathrm{hr})$ & 1 & 2 & 3 & 4 & 6 & 8 \\
\hline Urine volume (ml/hr) & $402 \pm 52$ & $228 \pm 51^{*}$ & $37 \pm 9^{*}$ & $33 \pm 7^{*}$ & $26 \pm 3^{*}$ & $34 \pm 4^{*}$ & $118 \pm 26^{*}$ \\
Uosm (mOsm $/ \mathrm{kg})$ & $91 \pm 8$ & $547 \pm 73^{*}$ & $686 \pm 24^{*}$ & $716 \pm 20^{*}$ & $732 \pm 21^{*}$ & $635 \pm 43^{*}$ & $331 \pm 85^{*}$ \\
Posm $(\mathrm{mOsm} / \mathrm{kg})$ & $288 \pm 3.5$ & $284 \pm 3.6$ & $283 \pm 3.1$ & $284 \pm 3.2$ & $284 \pm 2.8$ & $285 \pm 2.0$ & $284 \pm 2.7$ \\
Serum Na (mEq/l) & $144 \pm 1.4$ & $144 \pm 1.4$ & $144 \pm 1.5$ & $142 \pm 1.5$ & $142 \pm 1.2$ & $143 \pm 1.8$ & $143 \pm 1.4$ \\
\hline
\end{tabular}

*: $\mathrm{p}<0.01$ compared with baseline. 
urine volume was $5.9 \pm 0.5 \%$ (range: $3.9-8.8$ ) of the baseline level. At baseline, the mean Uosm was $91 \pm 8 \mathrm{mOsm} / \mathrm{kg}$ and increased progressively from $1 \mathrm{~h}$ and remained significantly elevated at $8 \mathrm{~h}$ with a mean maximal Uosm of $732 \pm 21 \mathrm{mOsm} / \mathrm{kg}$ being obtained after $4 \mathrm{~h}$. Mean Posm and serum sodium concentration remained unchanged for up to $8 \mathrm{~h}$. In one patient (Case 8), basal Posm and serum sodium concentration were above the normal range (Posm $310 \mathrm{mOsm} / \mathrm{kg}$, Na $154 \mathrm{meq} / \mathrm{l}$ ), while in another patient (Case 5), basal Posm was low at $269 \mathrm{mOsm} / \mathrm{kg}$. These abnormalities were not associated with clinical symptoms in either patient. In the remaining 7 patients, serum sodium levels and Posm remained within the normal range throughout the study (Fig. 3, Table 2).

\section{Long-term treatment}

One patient (Case 7) elected to withdraw from the long-term study because he considered it was troublesome to take the oral DDAVP on an empty stomach. Furthermore, polyuria in this patient was poorly controlled when the DDAVP was taken on a random basis. Oral DDAVP regime of the remaining 8 patients was monitored for $5 \mathrm{yr}$ and the doses of the pre-study intranasal and oral DDAVP treatments are summarised in Table 3. Mean dose of oral DDAVP required for

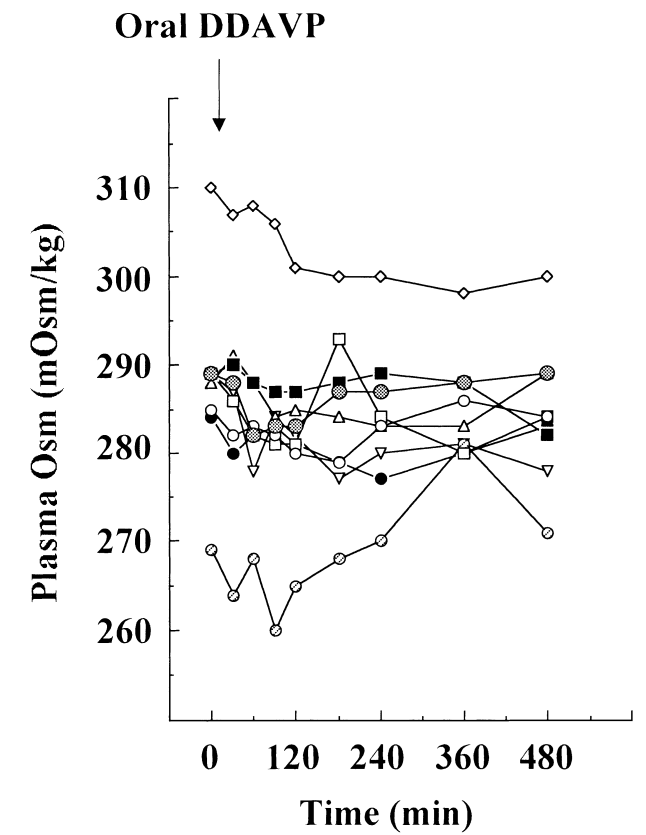

control of polyuria was $19 \pm 2$ times greater than intranasal treatment (range: $15-30$ times). Daily urine volume in all patients was well maintained during the $5 \mathrm{yr}$ period with mean volume measured over 3 consecutive days at the end of the study ranging from 1500 $1930 \mathrm{ml}$ per day (mean $1739 \pm 68 \mathrm{ml} /$ day). Posm levels of the patients remained stable with the exception of one patient (Case 8) whose Posm was occasionally greater than $290 \mathrm{mOsm} / \mathrm{kg}$. Otherwise, no adverse reactions or loss of efficacy of DDAVP was observed in any of the patients during the study period. The dose of oral DDAVP and daily urine volume over 1 month in a representative patient (Case 1) are shown in Fig. 4. In this patient, a DDAVP dosage of $500 \mu \mathrm{g} /$ day $(100$ $200 \mu \mathrm{g}$ tablet 4 times per day) produced normal and stable diuresis (mean 1836 \pm 114 , range 1090-3100 $\mathrm{ml} /$ day) after the third week of treatment comparable to the effect of the previous intranasal treatment.

\section{Discussion}

The findings of this study confirm earlier investigations [4-11] that oral administration of DDAVP has a marked antidiuretic action in patients with central DI with a dose of $100 \mu \mathrm{g}$ increasing Uosm and significantly reducing urine volume for up to $8 \mathrm{~h}$. While

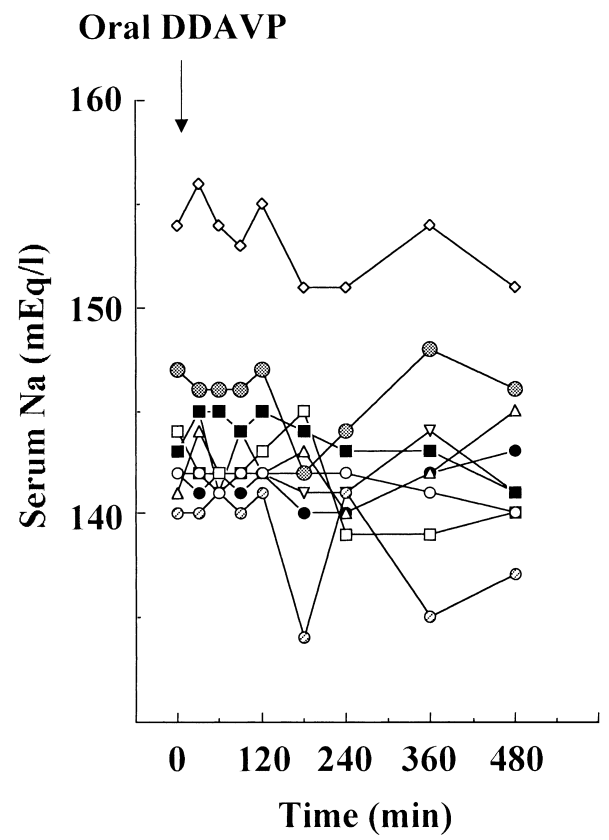

Fig. 3. Plasma osmolality and serum sodium levels in nine patients with DI after oral DDAVP administration. Symbols representing each case are the same as used in Fig. 1. 
Table 3. Results of five-year treatment with oral DDAVP

\begin{tabular}{|c|c|c|c|c|c|c|c|c|c|}
\hline \multirow[b]{2}{*}{ \# } & \multirow[b]{2}{*}{ Age, sex } & \multirow[b]{2}{*}{$\begin{array}{l}\text { Height } \\
(\mathrm{cm})\end{array}$} & \multirow[b]{2}{*}{$\begin{array}{l}\text { BW } \\
(\mathrm{kg})\end{array}$} & \multirow{2}{*}{$\begin{array}{c}\begin{array}{c}\text { Prior intranasal } \\
\text { treatment }\end{array} \\
\begin{array}{c}\text { dose } \\
(\mu \mathrm{g} / \mathrm{day})\end{array}\end{array}$} & \multicolumn{5}{|c|}{ Oral DDAVP treatment } \\
\hline & & & & & $\begin{array}{c}\text { dose } \\
(\mu \mathrm{g} / \text { day })\end{array}$ & $\mathrm{O} / \mathrm{N}^{*}$ & $\begin{array}{c}\text { Posm } \\
(\mathrm{mOsm} / \mathrm{kg})\end{array}$ & $\begin{array}{c}\text { Uosm } \\
(\mathrm{mOsm} / \mathrm{kg})\end{array}$ & $\begin{array}{c}\text { UV } \\
(\mathrm{ml} / \text { day) }\end{array}$ \\
\hline 1. & $17 \mathrm{~F}$ & 149.0 & 58.5 & $30(3 \mathrm{X})$ & $500(4 X)$ & 17 & 287 & 697 & 1836 \\
\hline 2. & $18 \mathrm{M}$ & 165.8 & 61.0 & $10(2 X)$ & $200(2 X)$ & 20 & 286 & 532 & not done \\
\hline 3. & $19 \mathrm{~F}$ & 152.9 & 64.0 & $30(2 X)$ & $600(3 X)$ & 20 & 283 & 899 & 1883 \\
\hline 4. & $20 \mathrm{~F}$ & 159.8 & 56.5 & $14(2 X)$ & $250(3 \mathrm{X})$ & 18 & 282 & 788 & 1873 \\
\hline 5. & $21 \mathrm{M}$ & 171.4 & 51.0 & $10(2 X)$ & $300(3 X)$ & 30 & 287 & 634 & 1500 \\
\hline 6. & $28 \mathrm{~F}$ & 158.9 & 60.0 & $20(2 X)$ & $300(3 X)$ & 15 & 273 & 580 & 1570 \\
\hline 7. & $30 \mathrm{M}$ & 159.0 & 62.0 & $8(2 X)$ & dropout & & & & \\
\hline 8. & $33 \mathrm{M}$ & 162.5 & 64.0 & $20(2 X)$ & $300(3 X)$ & 15 & 286 & 774 & 1583 \\
\hline 9. & $36 \mathrm{M}$ & 166.4 & 59.0 & $20(2 X)$ & $400(4 X)$ & 20 & 286 & 275 & 1930 \\
\hline
\end{tabular}

*: oral/intranasal dose ratio

$* *$ : mean urine volume of 3 days

\section{Oral DDAVP $(\mu \mathrm{g} / \mathrm{day})$}

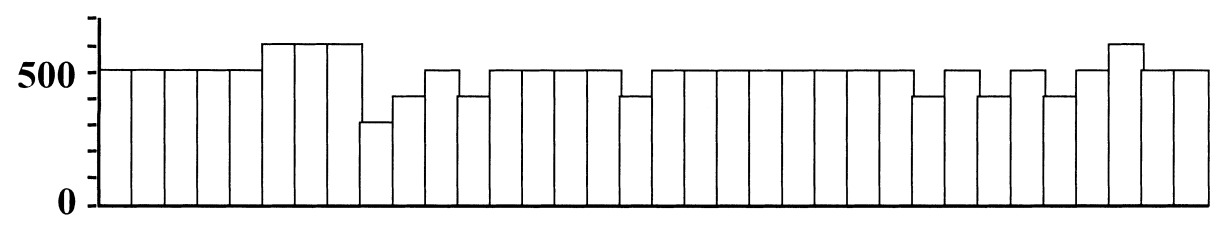

\section{Urine volume $(\mathrm{ml} / \mathrm{day})$}

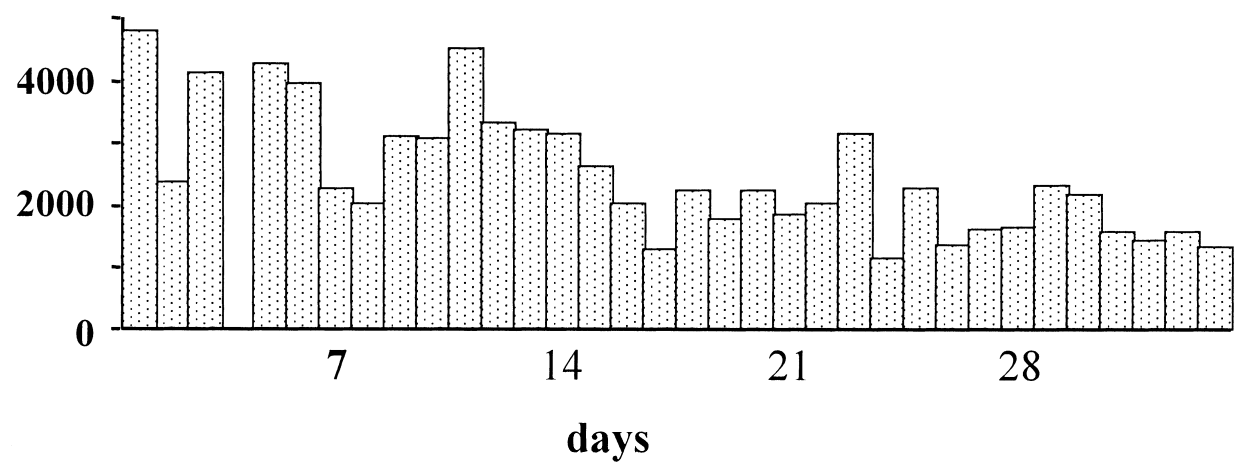

Fig. 4. Doses of daily oral DDAVP and changes in urine volume in a representative patient with DI (Case 1).

Hammer and Vilhardt [8] found these effects were dose dependent, one patient in our study required $200 \mu \mathrm{g}$ of oral DDAVP to maintain acceptable antidiuresis, suggesting that there may be large individual differences in the dose required to achieve efficacy. Two patients had an abnormal basal Posm, one of whom was high and the other low, although in both cases these abnormalities were not associated with clinical symptoms. Intranasal DDAVP was discontinued for one day prior to the study and water intake ad libitum was allowed until the baseline measurements. It is possible these factors may have played a role in the fluctuations of Posm although it was observed that oral DDAVP was not associated with any adverse changes in these levels.

Our study also demonstrated oral DDAVP was as effective as intranasal DDAVP for controlling central DI over a $5 \mathrm{yr}$ period and that this treatment was not associated with any adverse effects. However, higher dosages and more frequent administration of the oral DDAVP were required in order to achieve control comparable to intranasal administration of the compound. These findings are in accordance with FjellestadPausen et al. [9] who demonstrated the oral DDAVP 
doses required were approximately 20 times greater than intranasal doses, and Fjellestad and Czernichow [4] who found the recommended dose of oral DDAVP for children with central DI was $100-300 \mu \mathrm{g} 2-3$ times a day. In the present study, $200-600 \mu \mathrm{g}$ of oral DDAVP, 2-4 times a day was required in order to control polyuria in adult patients with central DI, a dose approximately 19 -fold higher than the equivalent dose of intranasal administration.

The efficacy of oral DDAVP was insufficient in one patient with DI caused by a germinoma (Case 8) to control Posm. On occasion this patient had an elevated Posm greater than $290 \mathrm{mOsm} / \mathrm{kg}$, although Uosm was always greater than Posm. Several possibilities may account for this poor control. First, this patient had a disorder in thirst response to hypertonic stimuli that maintained stable body fluid tonicity, as seen in his elevated Posm levels less frequently during intranasal therapy. Alternatively it is possible that the dose of oral DDAVP was insufficient to achieve Poms control although the dose of $300 \mu \mathrm{g} /$ day was 15 times greater than his prior intranasal dose. A third possibility was that gastrointestinal absorption in this patient was low as the DDAVP tablets were sometimes taken in conjunction with food. However, the results of single administration study in this patient revealed that the level of plasma DDAVP was highest among the patients (more than $50 \mathrm{pg} / \mathrm{ml}$ ) and Uosm reached more than $800 \mathrm{mOsm} / \mathrm{kg}$ at $6 \mathrm{~h}$. Therefore, it was likely that the first possibility was the main cause for this poor control, and that gastrointestinal absorption of DDAVP was not low when he took it on an empty stomach.
In conclusion this study demonstrated oral DDAVP administration was safe and effective for the control of polyuria in the majority of patients with central DI, although the dosage of this oral treatment was higher and required more frequently than intranasal administration of the drug. A possible disadvantage of oral DDAVP treatment was that the tablets needed to be taken on an empty stomach to avoid low gastrointestinal absorption. Nevertheless, there are also difficulties controlling diuresis with intranasal DDAVP in patients with frequent rhinitis or poor vision due to mass lesion causing DI in both young and elderly patients. In this regard, two patients with visual disturbances in our study following the use of oral DDAVP became more independent in their daily life as a consequence of no longer needing to ask for adjustment of DDAVP dosage as had been required for intranasal administration. Taken together the results of this study suggest that oral DDAVP may be an attractive alternative therapy for patients with central DI and polyuria.

\section{Acknowledgments}

We are grateful to Ferring AB Pharmaceuticals for providing the oral DDAVP for the entire period of this study. We would like to especially thank Dr. Anne M. Fjellestad-Paulsen who informed us that oral DDAVP was particularly effective in patients with visual disturbances and kindly gave us the opportunity to carry out further research on the use of this drug.

\section{References}

1. Vilhardt H, Bie P (1984) Antidiuretic effect of perorally administered DDAVP in hydrated humans. Acta Endocrinol (Copenhagen) 105: 474-476.

2. Williams TDM, Dunger DB, Lyon CC, Lewis RJ, Taylor F, Lightman SL (1986) Antidiuretic effect and pharmacokinetics of oral 1-deamino-8-D-arginine vasopressin. 1. Studies in adult and children. J Clin Endocrinol Metab 63: 129-132.

3. d'Agay-Abensour L, Fjellestad-Paulsen A, Hoglund P, Ngo Y, Paulsen O, Rambaud JC (1993) Absolute bioavailability of an aqeous solution of 1-deamino-8-Darginine vasopressin from different regions of the gastrointestinal tract in man. Eur J Clin Pharmacol 44: 473-476.

4. Fjellestad A, Czernichow P (1986) Central diabetes in- sipidus in children. Acta Paediatr Scand 75: 605-610.

5. Lundin S, Melin P, Vilhardt H (1985) Plasma concentrations of 1-deamino-8-D-arginine vasopressin after intragastric administration in the rat. Acta Endocrinol (Copenhagen) 108: 179-183.

6. Fjellestad-Paulsen A, Hoglund P, Lundin S, Paulsen O (1993) Pharmacokinetics of 1-deamino-8-D-arginine vasopressin after various routes of administration in healthy volunteers. Clin Endocrinol 38: 177-182.

7. Cunnah D, Ross G, Besser GM (1986) Management of cranial diabetes insipidus with oral desmopressin (DDAVP). Clin Endocrinol 24: 253-257.

8. Hammer M, Vilhardt H (1985) Peroral treatment of diabetes insipidus with a polypeptide hormone analog, Desmopressin. J Pharmacol Exper Ther 234: 754-760. 
9. Fjellestad-Paulsen A, Tubiana-Rufi N, Harris A, Czernichow P (1987) Central diabetes inspidus in children. Acta Endocrinol 115: 307-312.

10. Boulgourdjian EM, Martinez AS, Ropelato MG, Heinrich JJ, Bergada C (1997) Oral desmopressin treatment of central diabetes insipidus in children. Acta
Paediatr 86: 1261-1262.

11. Fjellestad-Paulsen A, Paulsen O, d'Agay-Abensour L, Lundin S, Czernichow P (1993) Central diabetes insipidus: oral treatment with dDAVP. Regul Pept 45: 303-307. 